dr inz: Marian Kaluba, prof. nadzw.

mgr inz. Damian Goliwas

Instytut Pojazdów Szynowych ,TABOR”

\title{
Modułowa uniwersalna tablica pneumatyczna dla lokomotyw spalinowych i elektrycznych
}

\begin{abstract}
$W$ artykule zaprezentowano nowy typ tablicy pneumatycznej, zrealizowany $w$ oparciu o opracowane $w$ Instytucie Pojazdów Szynowych TABOR w Poznaniu uniwersalne pneumatyczne moduly funkcjonalne, realizujace poszczególne układy sterowania hamulcami lub pneumatyczne uktady pomocnicze. Na bazie tych modulów można zbudować dowolnq tablice pneumatyczna, realizujaca wymagane przez zamawiajacego funkcje, dla wszelkich rodzajów modernizowanych $i$ nowo budowanych lokomotyw.

Przedstawiono zakres i sposób realizowania projektu oraz przykladowe wyniki badań modulu generujacego przebieg ciśnień sterowanych mikroprocesorowo. Dodatkowo, przedstawiono inne urzadzenia poza tablicowe, opracowane $i$ wdrożone do produkcji przez IPS TABOR, które z modulowa tablica pneumatycznq tworzq kompletne systemy sterowania hamulcami pojazdów trakcyjnych.

Prace zrealizowano $w$ ramach projektu celowego Nr ROW-III-276/2012: „Opracowanie uniwersalnej, modulowej tablicy pneumatycznej dla lokomotyw liniowych spalinowych i elektrycznych, integrującej wszystkie uktady pneumatyczne sterowania", wykonanej zgodnie z umowa: Nr III-176/P-193/2012/E z dnia 17.12.2012r. zawarta pomiędzy: Naczelna Organizcja Techniczna Federacja Stowarzyszeń Naukowo-Technicznych „NOT”, a Przedsiębiorstwem Wielobranżowym „Toolfas” Sp. z o.o. oraz Instytutem Pojazdów Szynowych TABOR w Poznaniu.
\end{abstract}

\section{WPROWADZENIE}

Współczesne systemy transportu i komunikacji kolejowej wymagają wielu różnego typu pojazdów trakcyjnych, tj.:

- autobusów szynowych,

- zespołów trakcyjnych:

- komunikacji miejskiej (metro, szybka kolej miejska),

- bliskiej komunikacji wokół aglomeracji miejskich,

- komunikacji międzymiastowej,

- dużych prędkości,

- lokomotyw:

- manewrowych,

- towarowych,

- liniowych osobowych.

Pojazdy te mogą być o napędzie spalinowym lub elektrycznym.

Każdy z tych rodzajów pojazdów wymaga nieco innego sterowania hamulcami $\mathrm{i}$ innego wyposażenia $\mathrm{w}$ pomocnicze układy pneumatyczne. Prowadzi to do konieczności realizowania wielu projektów i wdrożeń różnych układów sterowania hamulcami i układami pneumatycznymi pojazdu. Koszt realizacji tak wielu projektów jest duży, a czas niezbędny do ich wdrożenia długi.
Aktualną tendencją rozwojową systemów sterowania jest ich budowa modułowa $[1,2]$. Wówczas kompletne układy pneumatyczne hamulca i pneumatycznych układów pomocniczych pojazdów trakcyjnych są złożone $\mathrm{z}$ niezależnych modułów lub submodułów w zakresie sprzętu pneumatycznego i elektronicznego. Każdy rodzaj użytego na pojeździe układu hamulca jest najczęściej wydzielony i zabudowany $\mathrm{W}$ zespole (module) składającym się $\mathrm{Z}$ relatywnie prostego sprzętu pneumatycznego, sterowanego według odpowiedniego oprogramowania sterownikiem mikroprocesorowym. Układ sterowania hamulcami pojazdu trakcyjnego powstaje wówczas na zasadzie łączenia modułów ze sobą (integracji) na tablicy pneumatycznej.

Budowę modułową sterujących układów hamulcowych i pneumatycznych wymuszają następujące czynniki:

- zróżnicowane wymagania przewoźników względem wyposażenia pojazdu,

- duża różnorodność pojazdów trakcyjnych,

- zróżnicowane strategie wdrażania do produkcji pojazdów nowych i modernizowanych,

- poszukiwanie przez integratorów pojazdów kompromisu pomiędzy kosztami projektu i 
- zakresem realizowanych funkcji układów pneumatycznych,

- minimalizowanie kosztów projektowania i badań nowych układów oraz pojazdów (poprawa efektywności opracowywania nowych projektów),

- skracanie czasu niezbędnego do wdrożenia nowych układów hamulcowych i pojazdów.

Dzięki budowie modułowej uzyskuje się możliwość bardzo elastycznego kształtowania wielkości i charakterystyk układów sterowania hamulcami różnych rodzajów pojazdów trakcyjnych bez konieczności zmian w sprzęcie układów. Zapewnia to również dużą niezawodność, łatwość przeglądów i napraw, możliwość prowadzenia zaawansowanej diagnostyki układu, niskie koszty LCC i możliwość osiagnięcia wysokiego współczynnika dyspozycyjności pojazdu.

\section{PLANOWANIE PROJEKTU}

Prace nad modułową tablicą pneumatyczną realizowane były w latach 2012-2013 w ramach projektu celowego Nr ROW-III-276/2012 pn.: „Opracowanie uniwersalnej, modułowej tablicy pneumatycznej dla lokomotyw spalinowych i elektrycznych, integrujacej wszystkie układy pneumatyczne sterowania". Projekt ten, realizowany przez wielobranżowe przedsiębiorstwo Toolfas Sp. z o.o. i IPS TABOR, był współfinansowany przez Centrum Innowacyjności NOT.

Projekt został podzielony na badania przemysłowe, prace rozwojowe i prace wdrożeniowo-inwestycyjne. W ramach badań przemysłowych wykonano:

- analizę funkcji układów i podukładów sterowania hamulcami pojazdów i opracowanie struktury systemu z niezależnymi modułami funkcjonalnymi (IPS TABOR),

- opracowanie konstrukcji funkcjonalnych modeli modułów (IPS TABOR),

- opracowanie technologii wykonania modeli modułów i ich wykonanie (Toolfas),

- wykonanie podstawowych badań symulacyjnych modelu modułowej tablicy pneumatycznej dla lokomotywy liniowej.

Prace rozwojowe obejmowały:

- wykonanie wybranych modułów niezbędnych do skompletowania prototypowej tablicy pneumatycznej (Toolfas),

- wykonanie prototypu tablicy do badań, w szczególności wybór i opracowanie mikroprocesorowego systemu sterowania wraz z wyborem rodzaju (typu) magistrali danych oraz opracowanie algorytmów działania modułów funkcjonalnych i ich oprogramowanie (IPS TABOR),

- przeprowadzenie prób i badań prototypu modułowej tablicy pneumatycznej (IPS TABOR).

$\mathrm{W}$ ramach prac wdrożeniowo-inwestycyjnych zrealizowano:
- opracowanie docelowej dokumentacji produkcyjnej serii informacyjnej modułów i wybranego rodzaju tablicy modułowej,

- wykonanie serii informacyjnej 5 kompletów modułów dla wybranego typu tablicy pneumatycznej (Toolfas)

- opracowanie dokumentacji technologicznokonstrukcyjnej do produkcji modułów tablicy pneumatycznej (IPS TABOR).

$\mathrm{Na}$ rysunku 1 pokazano prototypowe wykonanie modułowej tablicy pneumatycznej wyprodukowanej w ramach realizowanego projektu.

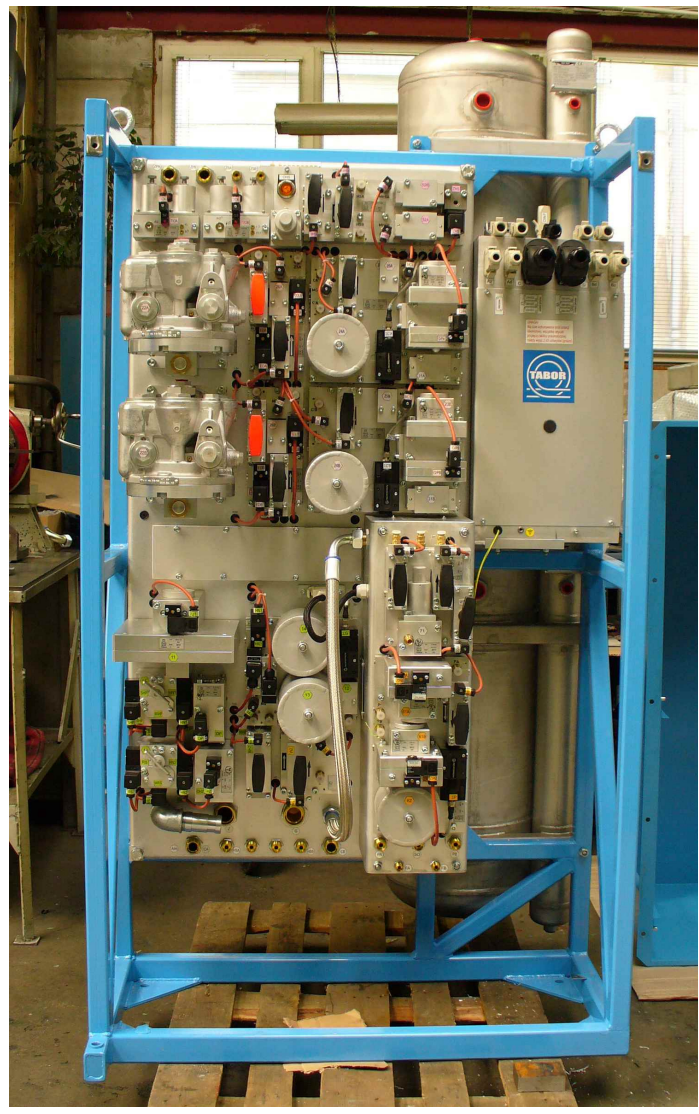

Rysunek 1. Prototypowe wykonanie dwuobwodowej modułowej tablicy pneumatycznej

\section{PODZIAL STRUKTURALNY I FUNKCJO- NALNY PROJEKTOWANEGO UKLADU STEROWANIA HAMULCAMI I PNEUMA- TYKĄ LOKOMOTYW}

W ramach prac wstępnych prowadzonych przez IPS TABOR dokonano podziału strukturalnego i funkcjonalnego systemów pneumatycznych pojazdów trakcyjnych. Elementy układów sterowania hamulcami i pneumatyką podzielono na trzy grupy strukturalne:

- układy elektronicznego sterowania hamulcami EBC (elektronic brake control),

- pneumatyczne układy sterowania hamulcami PBC (pneumatic brake control) oraz pneumatyczne układy pomocnicze i zasilające PAC (pnematic auxiliary control),

- pulpitowe urządzenia sterujące. 
Ustalono następujący podział funkcjonalny układów sterowania hamulcami i układami pneumatycznymi:

- układ hamulca zespolonego pociagu (funkcja zaworu maszynisty dla lokomotyw lub dla zespołów trakcyjnych),

- układ hamulca dodatkowego (hamulec bezpośredni dla lokomotyw),

- lokomotywowy układ sterowania hamulcem elektropneumatycznym pociagu zestawionego z wagonów (typu automatycznego EP-A) i mostkowania uruchomionego przez pasażera hamulca bezpieczeństwa w wagonie pociagu,

- układ hamulca elektropneumatycznego typu bezpośredniego EP-B (dla zespołów trakcyjnych), ze sterowaniem binarnym lub ze sterowaniem sygnałem o zmiennej szerokości pulsu,

- układ realizujący ciagłą i płynną zmianę siły hamowania pojazdu w funkcji przewożonego ładunku z możliwością korekcji zapewniającej stałe opóźnienie pojazdu (wyposażonego w hamulec klockowy),

- układ realizujący skokową zmianę siły hamowania w funkcji przewożonego ładunku (jako tańsza alternatywa płynnej zmiany siły hamowania w funkcji ładunku dla pojazdów o względnie niewielkim przewożonym ładunku),

- układ hamulca szynowego,

- układ współpracy hamulca elekrodynamicznego (ED) z hamulcem pneumatycznym (tzw. blending),

- układ samoczynnego hamowania pociagu (SHP),

- układ zdalnego hamowania pociagów na sygnał radiowy (Radiostop) lub ETCS,

- układ czuwaka aktywnego,

- układ hamulca bezpieczeństwa pasażerów,

- układ mostkowania hamulca bezpieczeństwa pasażerów dla zespołów trakcyjnych,

- układ hamulca postojowego,

- układ syren i generowania sygnałów alarmowych,

- układ podnoszenia odbieraków,

- układ zasilania piasecznic,

- układ zasilania smarowania obrzeży,

- układ blokady szaf wysokiego napięcia,

- układ rozrządu sprężonego powietrza dla aparatów elektrycznych,

- układ zasilania usprężynowania pneumatycznego pojazdu,

- układ diagnostyki parametrów hamulca i pomocniczych obwodów pneumatycznych,

- układ wspierający realizację prób stacjonarnych wykonywanych przez maszynistę, obejmujący automatyczne przeprowadzenie próby stacjonarnej hamulca.

W każdym z wymienionych układów funkcjonalnych do realizacji wymaganych funkcji niezbędne są urządzenia ze wszystkich trzech grup strukturalnych wymienionych wyżej. Na ogół udaje się w każdej z tych grup stworzyć powtarzalne moduły lub submoduły strukturalne, które realizują wymagane funkcje.

\subsection{PNEUMATYCZNE MODULY TABLICOWE (PBC, PAC)}

W wyniku przeprowadzonych analiz wytypowano do realizacji w ramach projektu (dla lokomotywowych modułowych uniwersalnych tablic pneumatycznych) następujące moduły:

- moduły układów hamulcowych mocowanych do korpusu głównego tablicy pneumatycznej, mogące występować we wszystkich rodzajach lokomotyw (Rysunek 2.):

- zasilania (moduł zaworu WZ),

- sterowania ciśnieniem w przewodzie głównym (moduł przewodu głównego HZP),

- hamulca klockowego czyszczącego (moduł HKc),

- zaworu rozrządczego lokomotywy,

- wyłącznika jednoobwodowego hamulca zespolonego lokomotywy (moduł WHZL1),

- przekładnika ciśnienia tablicy jednoobwodowej (moduł HZL1),

- hamulca dodatkowego tablicy jednoobwodowej (moduł HD1),

- hamulca postojowego sprężynowego tablicy jednoobwodowej (moduł HS1),

- wyłącznika dwuobwodowego hamulca zespolonego lokomotywy (moduł WHZL2),

- przekładnika ciśnienia tablicy dwukanałowej (moduł H(ZL+D)2),

- hamulca postojowego sprężynowego tablicy dwuobwodowej (moduł HS2),
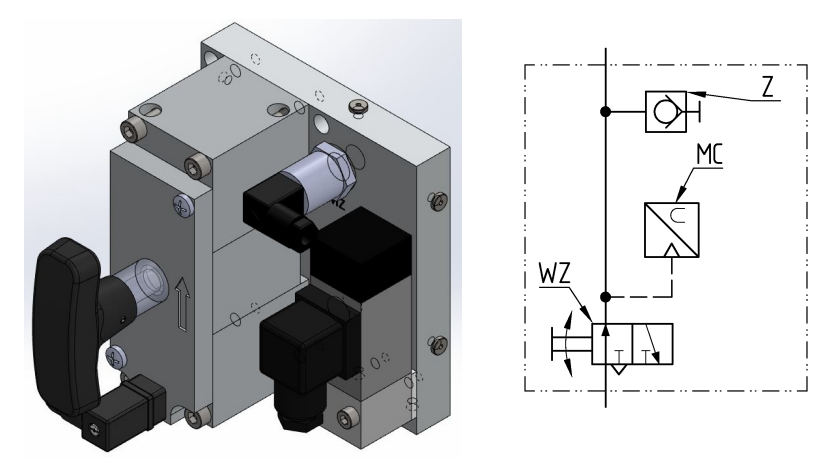

a) Moduł wyłącznika zasilania 20ZH 4AA 

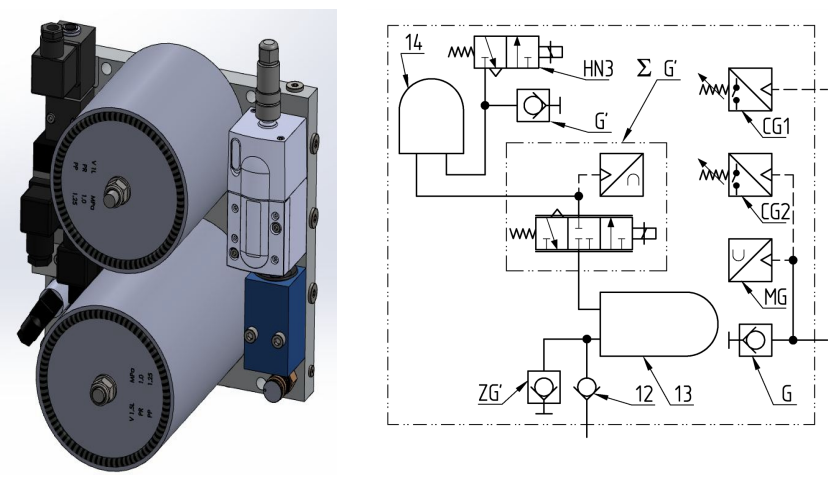

b) Moduł przewodu głównego 20ZH 4BA
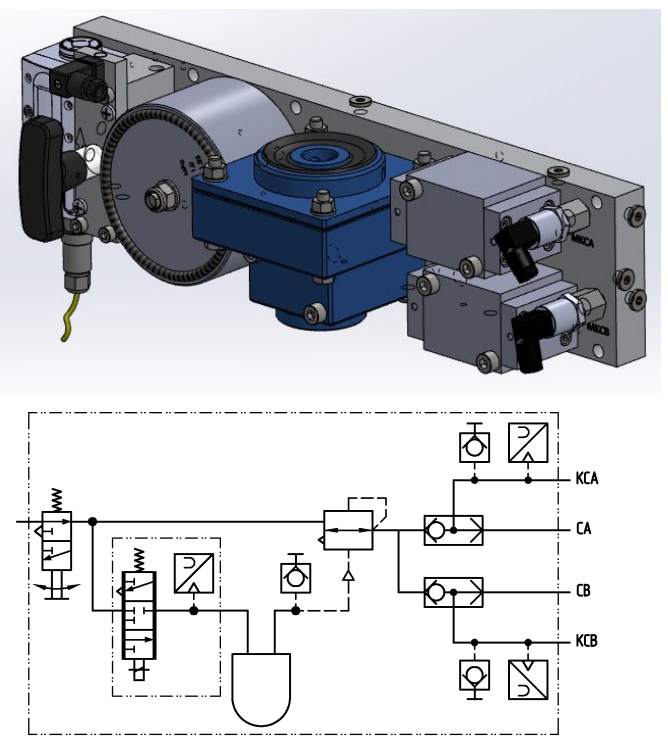

c) Moduł klocków czyszczących 20ZH 4CA
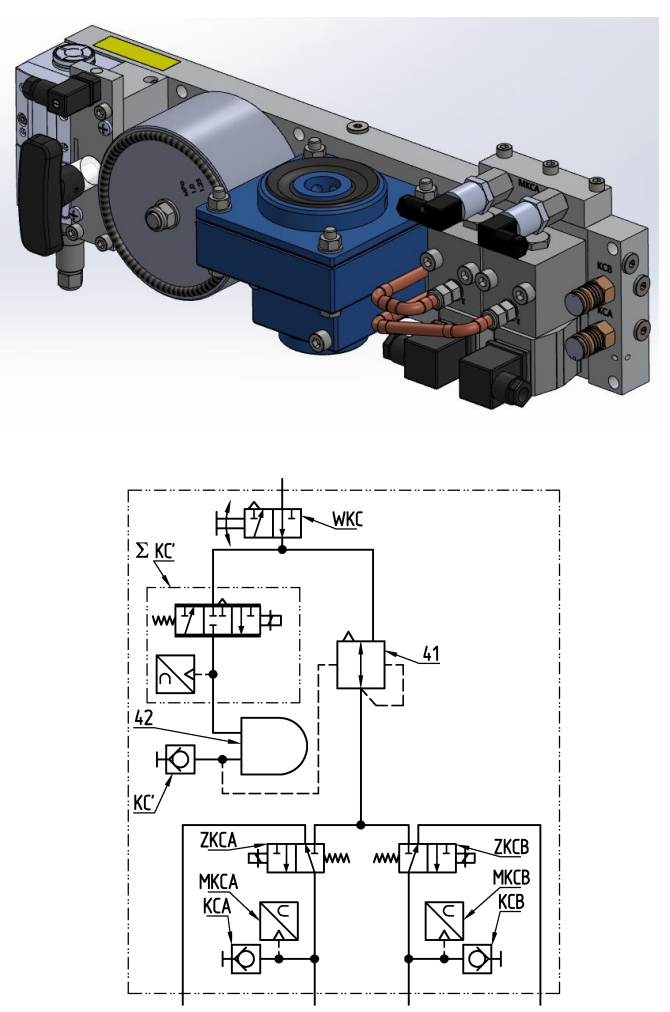

d) Moduł klocków czyszczących 20ZH 4CB

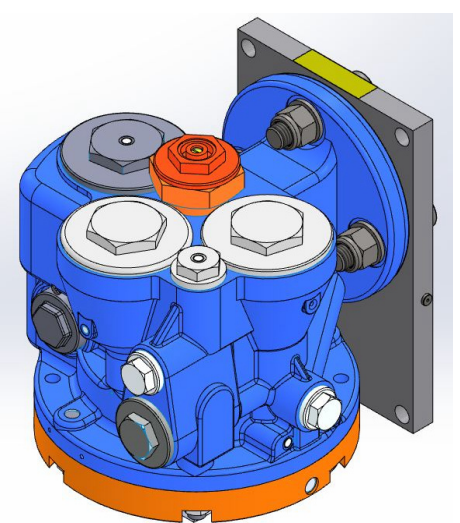

e) Moduł zaworu rozrządczego 20ZH 4DA
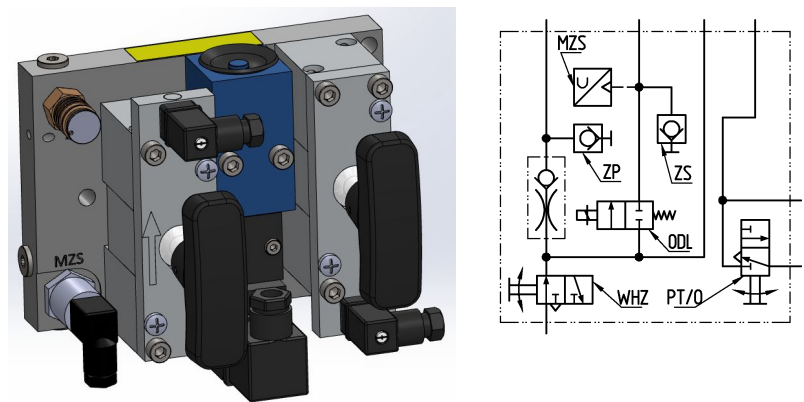

f) Moduł wyłączania zaworu rozrządczego 20ZH 4EA (jednoobwodowy)
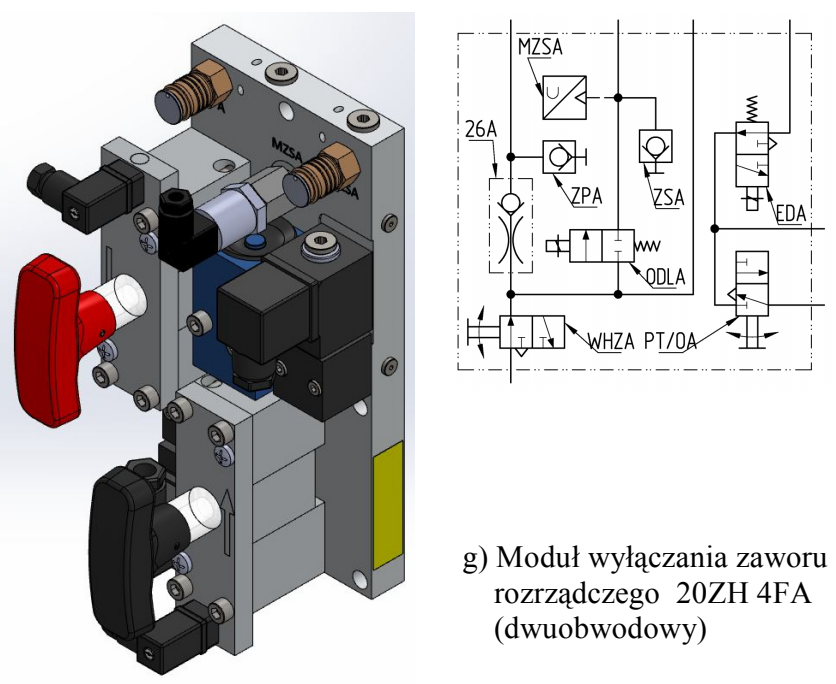

g) Moduł wyłączania zaworu rozrządczego 20ZH 4FA (dwuobwodowy)
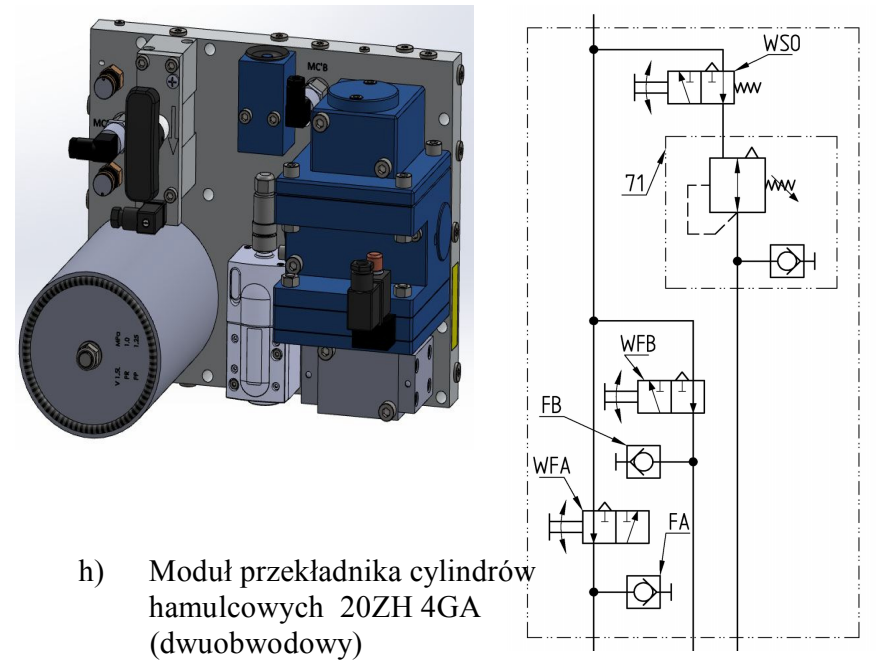


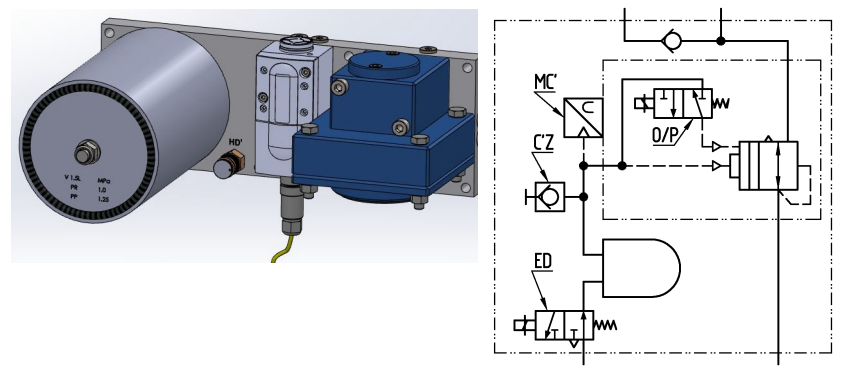

i) Moduł hamulca dodatkowego 20ZH 4JA
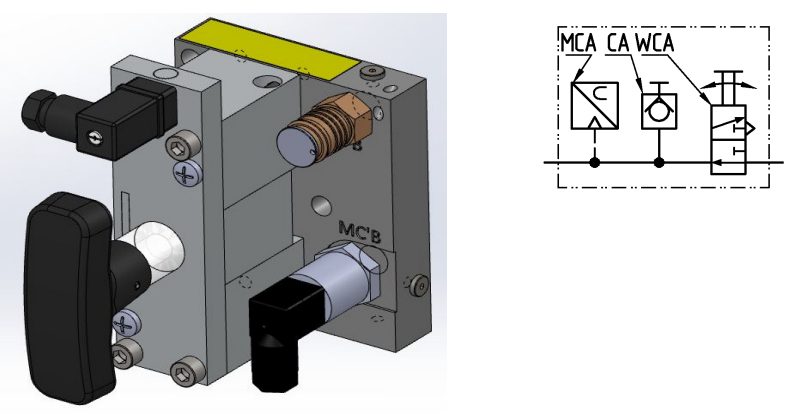

j) Moduł obwodu cylindrów 20ZH 4KA

Rysunek 2. Wizualizacje modułów zasadniczych dla modułowych tablic pneumatycznych
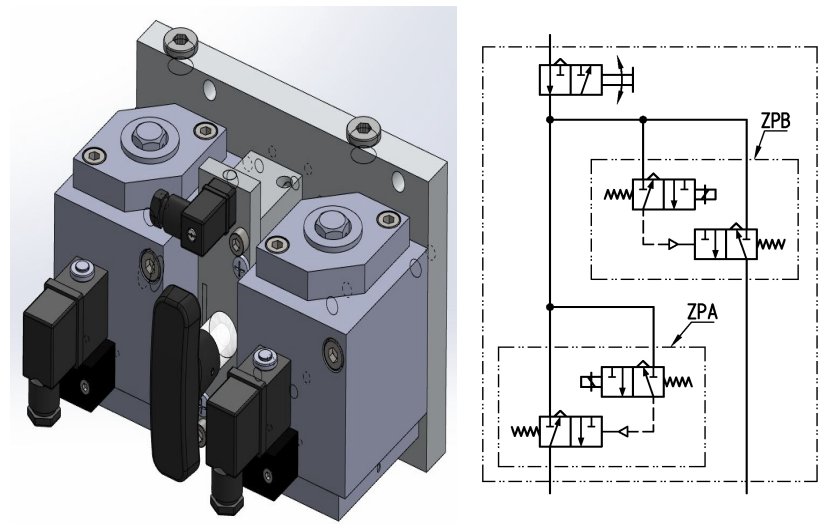

a) Moduł piasecznic $\mathrm{p} \neq \mathrm{f}(\mathrm{v})$ 20ZH 5AA
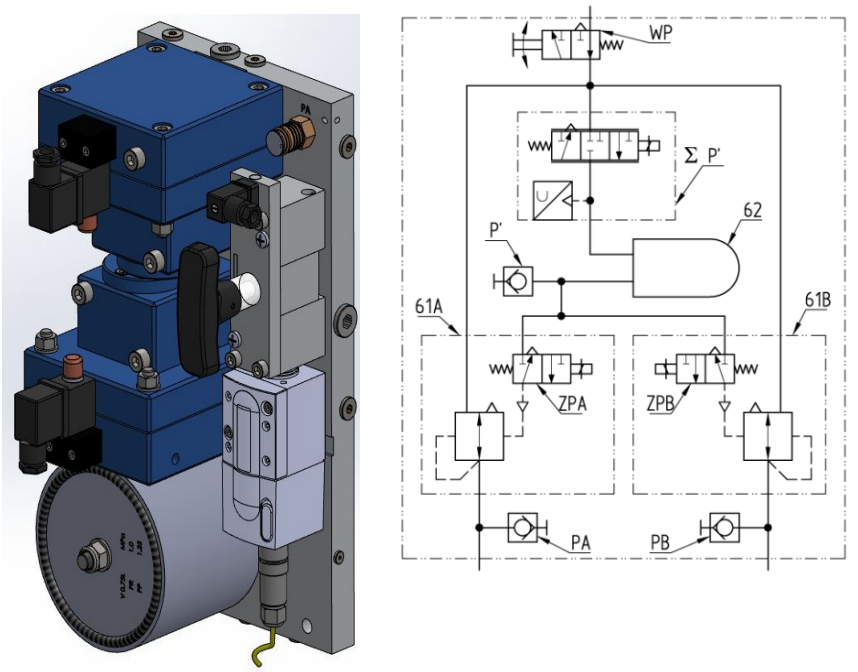

b) Moduł piasecznic $\mathrm{p}=\mathrm{f}(\mathrm{v})$ 20ZH 5BA
- moduły układów pomocniczych mocowane do korpusu głównego lub na nadstawce tablicy, przeznaczone dla wybranego typu lokomotywy lub na życzenie zamawiającego (Rysunek 3.):

- piasecznic (moduł 2P lub moduł 2Pv),

- zbiornika rozrządu (moduł ZR),

- smarowania obrzeży kół (moduł SO),

- syren (moduł 2(S+CS)),

- odbieraków prądu (moduł 2OP+B).
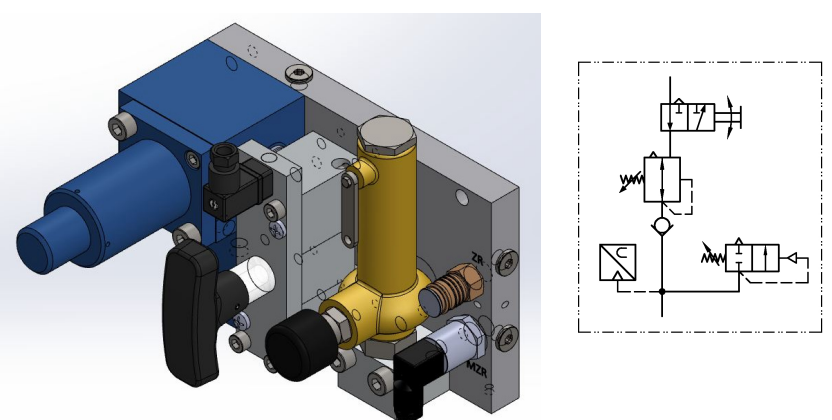

c) Moduł zbiornika rozrządu 20ZH 5CA
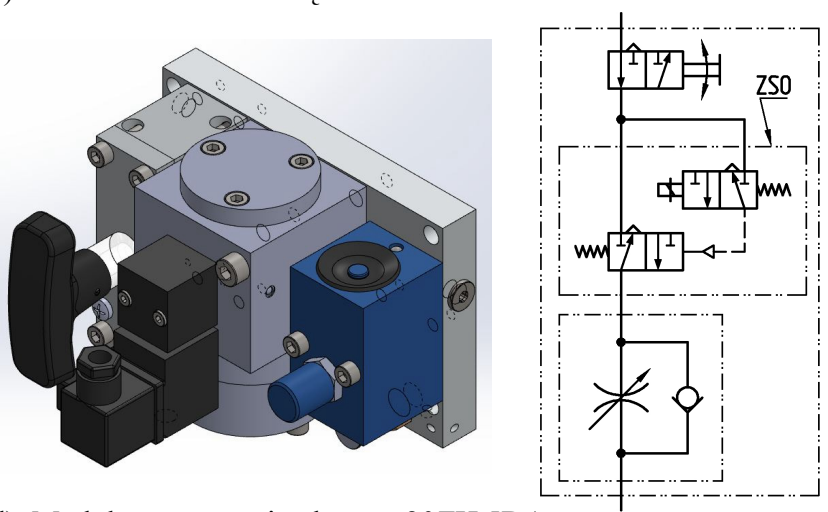

d) Modułu smarowania obrzeży 20ZH 5DA
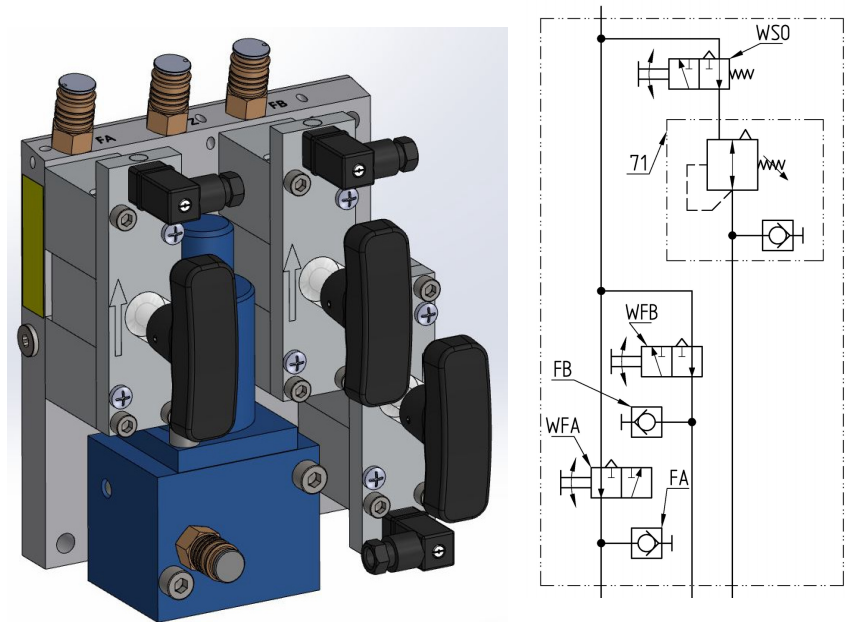

e) Moduł smarowania obrzeży i zasilania foteli 20ZH 5GA

Rysunek3. Wizualizacje modułów pomocniczych dla modułowych tablic pneumatycznych

Opracowane moduły znajdują zastosowanie w wielu różnych układach funkcjonalnych. Ich funkcje cząstkowe zostały tak zdefiniowane, że na bazie przyjętej i ograniczonej liczby modułów o wyznaczonych funkcjach, można tworzyć kompletne dowolne układy pneumatyczne. Zapewnia to możliwość 
skonfigurowania w relatywnie krótkim czasie bardzo różnorodnych układów sterowania hamulcami i układami pomocniczymi, dedykowanymi dla konkretnej lokomotywy. Po zintegrowaniu modułów na tablicy pneumatycznej, wszystkie $\mathrm{w}$ ten sposób powstałe układy pneumatyczne hamulca, są zgodne z aktualnymi wymaganiami międzynarodowymi (UIC, TSI) oraz dodatkowo mogą spełniać specyficzne wymagania klienta.

\subsection{ELEKTRONICZNE MODULY TABLICOWE (EBC)}

IPS TABOR opracował i wdrożył do produkcji rodzinę modułów elektronicznych - sterowników mikroprocesorowych. Zrealizowano idee, w której kilka modułów (sterowników) mocowanych na listwie montażowej połączonych siecią informatyczną między sobą, tworzy kompletny mikroprocesorowy układ sterowania całą pneumatyką danego pojazdu (Rysunek 4.).

W takim układzie wydzielone sterowniki realizuja centralne sterowanie hamulcami: sterują wartościami regulowanych ciśnień, realizują funkcje dla poszczególnych układów oraz funkcję wejść i wyjść sprzętowych i programowych poprzez sieć informatyczną (np. CAN lub RS485).

Przyjęto zasadę, że moduły te stanowią część całkowicie zintegrowaną $\mathrm{z}$ tablicą pneumatyczna, to znaczy część elektryczna zabudowywana jest zawsze bezpośrednio na tablicy pneumatycznej lub $\mathrm{w}$ obudowach połączonych mechanicznie z tablicą pneumatyczną.

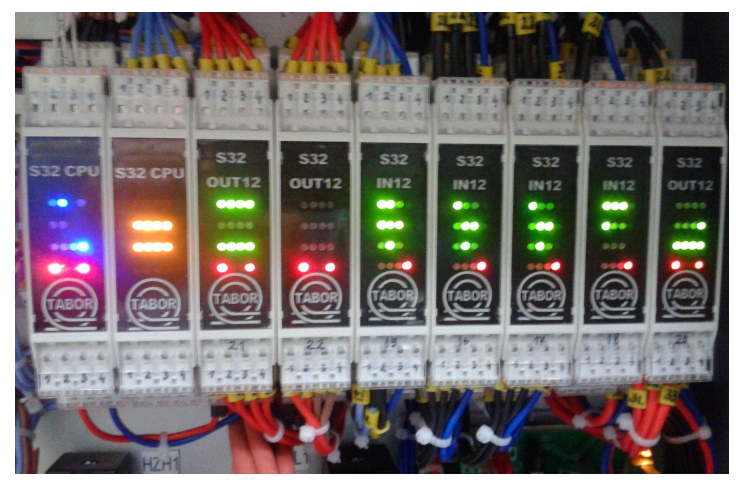

Rysunek 4. Sterownik mikroprocesorowy z modułami I/O

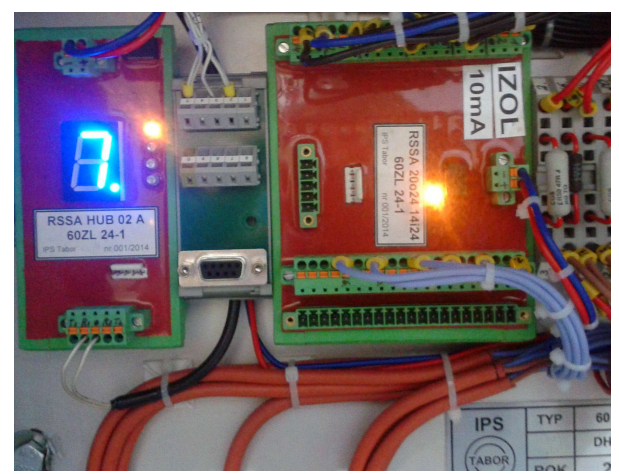

Rysunek 5. Sterownik mikroprocesorowy z modułami I/O
Zaletą takiego rozwiązania jest istotne ograniczenie okablowania na pojeździe (nie ma osobnej skrzyni lub kasety z układami elektronicznymi, jak to realizują inne firmy, i co za tym idzie brak jest dodatkowych połączeń pomiędzy częścią elektryczną, a tablicą pneumatyczna), przez co upraszcza się i istotnie przyspiesza montaż układu hamulca na pojeździe oraz zapewnia się jego bezproblemowe uruchomienie na pojeździe. Dodatkową zaletą jest również to, że kompletny układ pneumatyczno-elektryczny zajmuje bardzo mało miejsca.

Opracowano następujące moduły układów elektronicznych i mikroprocesorowych:

- zasilacz (V24B24),

- sterownik mikroprocesorowy (sterownik CPU 32 bitowy),

- moduł wejść sygnałów cyfrowych (moduł S32 IN12),

- moduł wejść sygnałów analogowych (moduł S32 AIN6),

- moduł wyjść sygnałów cyfrowych (moduł S32 OUT12),

- moduł wyjść sygnałów analogowych (moduł S32 AOUT8),

- moduł komunikacji CAN (moduł S32 2CAN),

- moduł komunikacji RS485 (modul S32 4RS485).

$\mathrm{Z}$ modułów tych można zbudować dowolnie złożony układ sterowania mikroprocesorowego pneumatyką pojazdu trakcyjnego.

W zakresie modułów generujących ciśnienia sterujące na sygnał elektryczny (na przykład dla ciśnień sterujących przekładników), opracowano dwa moduły, tzw. wyspy zaworowe, które w jednym korpusie posiadają dwa lub cztery zawory elektropneumatyczne sterowane mikroprocesorowo. Wyspy zaworowe przedstawiono na rysunku 5. Moduły te mogą występować pojedynczo lub w zależności od potrzeb można je łączyć ze sobą w wyspy wielozaworowe. Realizuja one we współpracy z mikroprocesorowymi regulatorami wymagane przebiegi ciśnień w funkcji czasu, dla wszelkich układów w których występuje potrzeba sterowania ciśnieniem $\mathrm{w}$ funkcji czasu sygnałami elektrycznymi.

Alternatywnie, opracowano moduły $\mathrm{z}$ analogowymi kolejowymi przetwornikami prąd-ciśnienie produkcji firmy Norgren, które w powiązaniu ze sterownikiem mikroprocesorowym tablicy również moga realizować dowolne zadane przebiegi ciśnień w funk$\mathrm{Na}$ rysunku 6 przedstawiono przykład działania modułu sterowania mikroprocesorowego odpowiedzialnego za generowanie przebiegu ciśnienia sterującego. 


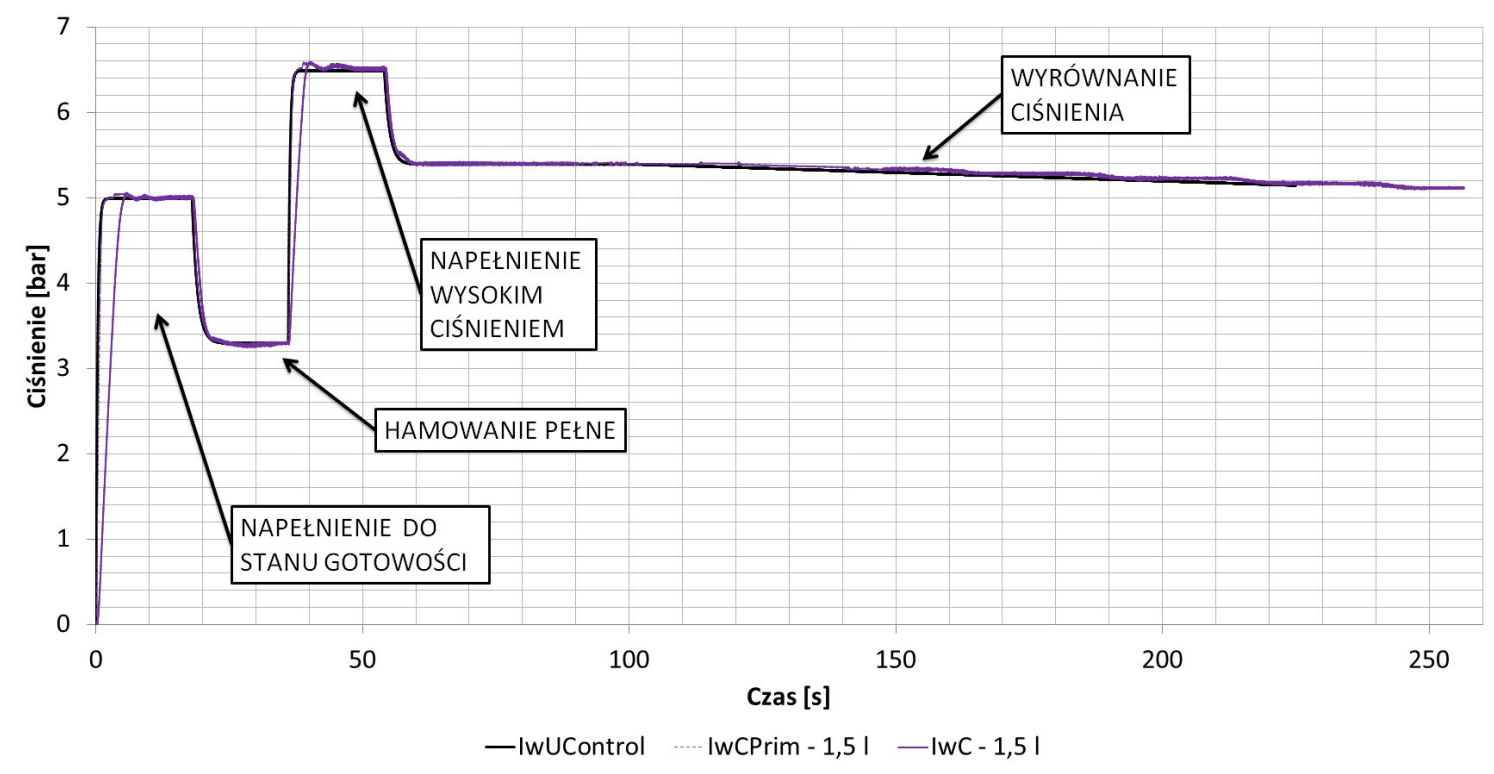

Rysunek 6 . Przykładowy przebieg sygnału sterującego i ciśnienia w przewodzie głównym

\section{URZĄDZENIA WSPÓLPRACUJĄCE Z MO- DULOWA TABLICĄ PNEUMATYCZNA}

Osobną grupe stanowią urządzenia, produkowane przez Instytut Pojazdów Szynowych TABOR w Poznaniu, zabudowane poza modułowymi tablicami pneumatycznymi [3], które tworzą system sterowania mikroprocesorowego układem pneumatycznym (w tym hamulcami) pojazdu:

- mikroprocesorowy sterownik układu przeciwpoślizgowego dla pojazdów cztero-osiowych lub sześcioosiowych współpracujący z czujnikami prędkości firmy Lenord; przygotowany w ramach innych prac rozwojowych prowadzonych przez IPS TABOR (Rysunek 7.)

- manipulatory pulpitowe układów hamulca (zespolonego, dodatkowego i napędu) opracowane zgodnie $\mathrm{z}$ wytycznymi karty UIC 612-0 [4], (Rysunek 8.)

- mikroprocesorowe, analogowe czujniki obciążenia pojazdu ładunkiem dla układu z automatyczną i płynną zmianą skuteczności hamowania (zmiany ciśnienia w cylindrach) w funkcji ładunku, które umożliwiają na pojeździe łatwą regulację układu ważenia poprzez ich kalibrowanie dla stanu pojazdu obciążonego połową ładunku - dokonuje się to poprzez hermetyczny przycisk na czujniku. Czujniki te znajdują zastosowanie w pojazdach z płynną zmianą siły hamowania $\mathrm{w}$ funkcji przewożonego ładunku, a nie posiadających usprężynowania pneumatycznego i nie mających możliwości zabudowy pneumatycznych naciskowych zaworów ważących. Rozwiązanie to znalazło powszechne zastosowanie $\mathrm{w}$ modernizowanych $\mathrm{w}$ ostatnich dwu latach zespołach trakcyjnych
EN57. (Rysunek 9.)

- zawory hamulca bezpieczeństwa maszynisty spełniające aktualne wymagania karty UIC 612-0 [4] (Rysunek 10.)
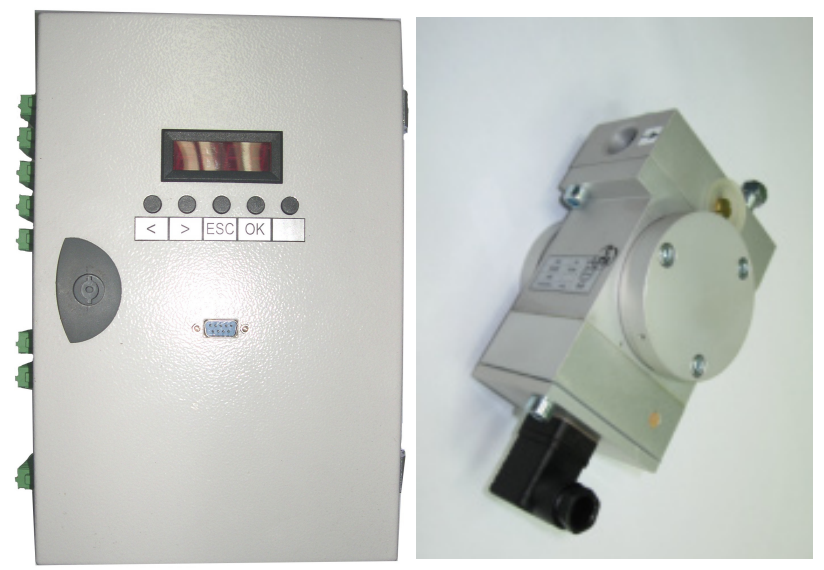

Rysunek 7. Sterownik układu przeciwpoślizgowego wraz z zaworem upustowym (po prawej)
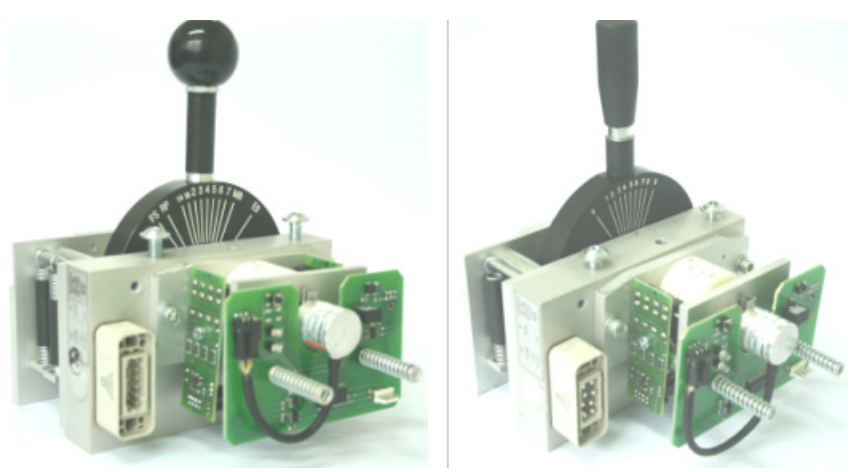

a) Manipulator hamulca zespolonego

b) Manipulator hamulca dodatkowego 

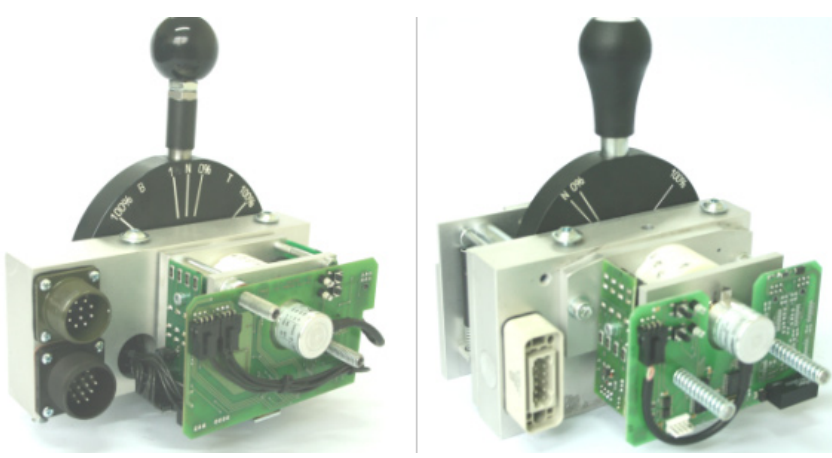

c) Manipulator napędu i hamowania d) Manipulator napędu

Rysunek 8. Rodzina manipulatorów pulpitowych (bez osłon)

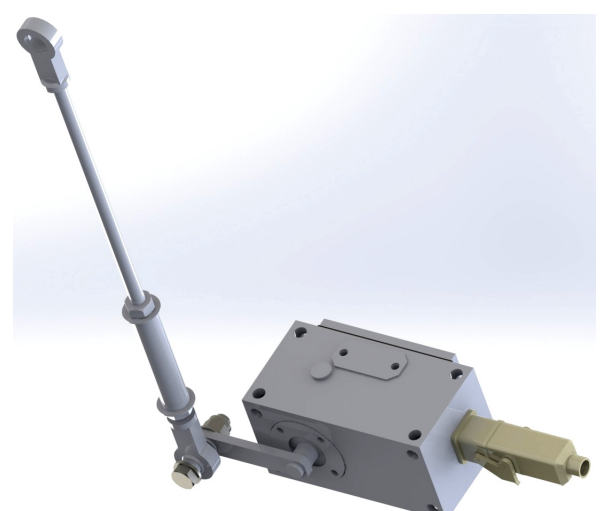

Rysunek 9. Analogowy czujnik obciążenia pojazdu ładunkiem

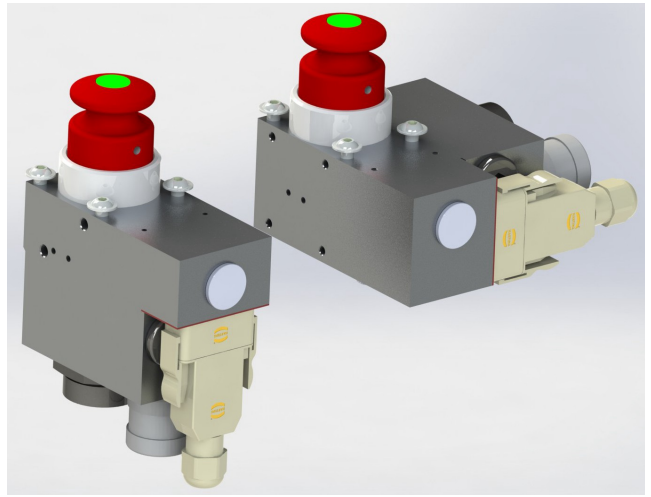

Rysunek 10. Kabinowy zawór hamulca bezpieczeństwa maszynisty

Kolejnymi modułami pneumatycznymi opracowanymi przez IPS TABOR są moduły diagnostyczne służące do kontroli wartości ciśnień.

Moduły diagnostyczne składają się z czujników ciśnienia, wyłączników ciśnienia i króćców pomiarowych w postaci szybkozłączy (Rysunek 11.).

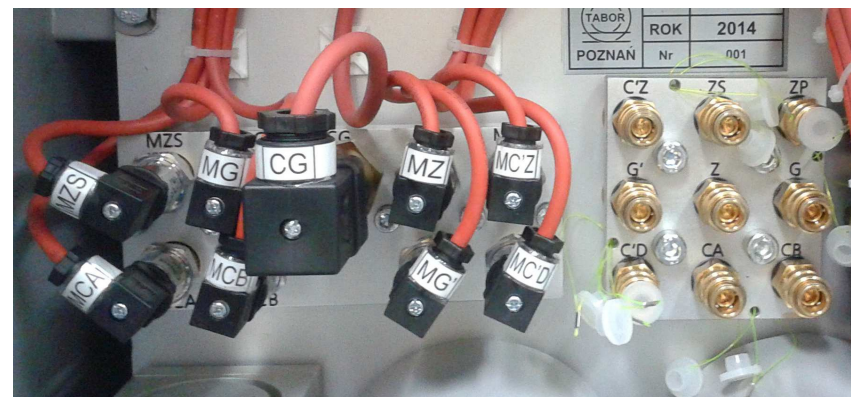

Rysunek 11. Moduły diagnostyczne

\section{PODSUMOWANIE}

IPS TABOR, na bazie opracowanych modułów, integrując je na tablicy pneumatycznej może skonfigurować kompaktowy układ sterowania, nawet o bardzo rozbudowanej strukturze funkcjonalnej, spełniający aktualne wymagania międzynarodowe (TSI, UIC), jak i szczególne wymagania operatorów kolejowych i integratorów (producentów) pojazdów. Dzięki temu czas przygotowania systemu pneumatycznego dla danego pojazdu trakcyjnego, o dowolnym zakresie realizowanych funkcji, łącznie z fizyczną realizacją, wynosi zaledwie kilka miesięcy.

Opracowywane przez IPS TABOR modułowe tablice pneumatyczne, jak również inne urządzenia, dzięki zabudowanym terminalom do transmisji danych, umożliwiają komunikację z nadrzędnym sterownikiem pojazdu poprzez różne magistralę (RS, CAN).

Wyprodukowane przez Instytut Pojazdów Szynowych „TABOR” w Poznaniu dwuobwodowe (z zaworem rozrządczym dla każdego wózka) modułowe tablice pneumatyczne typu 60ZL 24-1 zostały zabudowane w lokomotywach 111Db produkcji PESA Bydgoszcz.

\section{Bibliografia}

[1] Paddison J., Berger P.: Qualitätssicherung durch modulare Bauweise am Beispiel von Bremssteuerungssystem für die USA und Europa, ZEV+DET Glas. Ann. 125 (9/10. 2001).

[2] Modulares Bremssystem für die Baureihe 185, ZEV+DET Glas. Ann. 127 (01. 2003).

[3] Kaluba M., Goliwas D.: Modułowy system sterowania hamulcami pojazdów trakcyjnych. Pojazdy Szynowe. 2012. $\mathrm{Nr} 4$.

[4] Karta UIC 612-0: Interfejsy maszynista-pojazd dla EMU/DMU, lokomotyw $i$ napędnych wagonów pasażerskich. Funkcjonalne $i$ systemowe wymagania zwiqzane ze wspótpracujacymi interfejsami maszynista-pojazd

[5] Decyzja Komisji nr 2011/291/UE z dnia 26 kwietnia $2011 r$. w sprawie technicznej specyfikacji interoperacyjności odnoszqcej się do podsystemu „,Tabor - lokomotywy i tabor pasażerski" $w$ transeuropejskim systemie kolei konwencjonalnych 